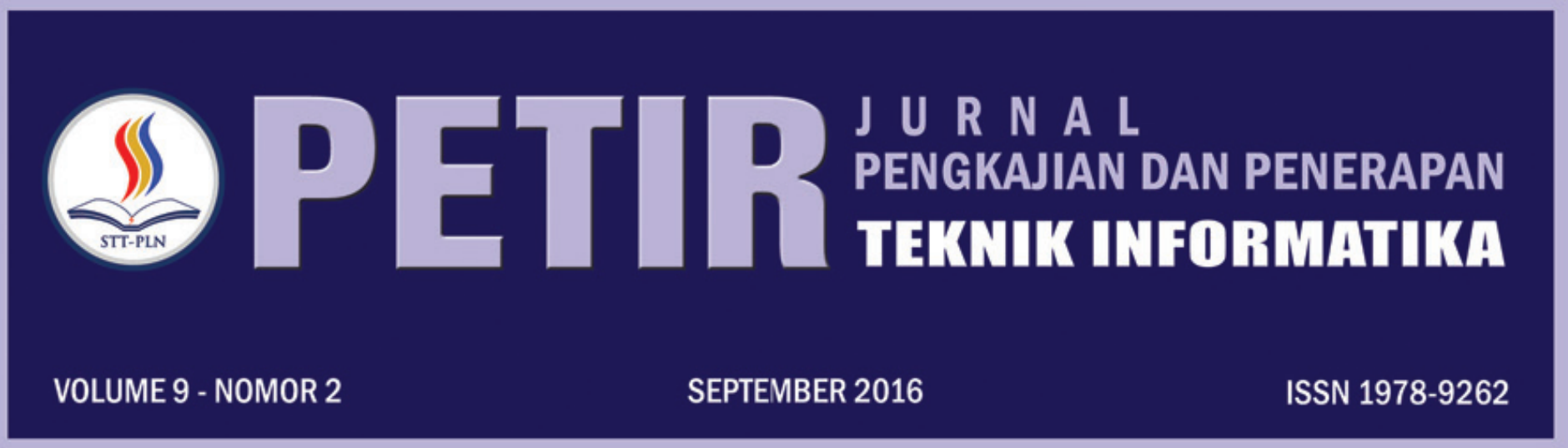

ANALISA SPASIAL UNTUK MELIHAT TINGKAT KESEJAHTERAAN MASYARAKAT DI PROVINSI BANTEN Muhamad Jafar Elly; Reza Pahlevi

PENENTUAN WILAYAH RAWAN PENYAKIT BERBASIS LINGKUNGAN DI JAKARTA TIMUR MENGGUNAKAN SISTEM INFORMASI GEOGRAFIS

Atiqah Meutia Hilda; Muhamad Jafar Elly; Windu Nugroho Cahyo Pamungkas

APLIKASI PENCARIAN USTADZ UNTUK WILAYAH DKI JAKARTA MENGGUNAKAN ALGORITMA HAVERSINE FORMULA BERBASIS ANDROID

Harni Kusniyati; Haries Fadhillah

PERENCANAAN ARSITEKTUR ENTERPRISE PERGURUAN TINGGI DENGAN PENDEKATAAN ENTERPRISE ARCHITECTURE PLANNING (EAP) (STUDI KASUS POLITEKNIK PIKSI GANESHA)

M. Farid Rifai

PERANCANGAN E-KATALOG PADA PERPUSTAKAAN DIGITAL STT-PLN BERBASIS WEB

Yessy Fitriani; Yasni Djamain; Risalatulina Dwi Kurniati

APLIKASI SISTEM GPS KEGIATAN OPERASIONAL PERSAMPAHAN DINAS PENGELOLAAN SAMPAH, PERTAMANAN DAN PEMAKAMAN (DP4) KOTA SUKABUMI

Yasmi Afrizal; Julian Chandra W
PERANCANGAN APLIKASI PENGOLAHAN DATA KAS BERBASIS ONLINE
(STUDI KASUS : KEMENTRIAN ' $X$ ')
Dian Hartanti; Lingga Desyanita

PERANCANGAN SISTEM INFORMASI PESERTA SERTIFIKASI

(Studi kasus LSP Piksi Ganesha)

Hendra Jatnika

RANCANG BANGUN APLIKASI SEC-WAY GUNA PENGINGAT BEPERGIAN DILENGKAPI INFO CUACA DAN CCTV JALAN RAYA LOKASI PILIHAN BERBASIS ANDROID STUDI KASUS DKI JAKARTA

Yasni Djamain; Intan Ratna Sari Yanti; Hari Wibowo

PREDIKSI PENERIMAAN SISWA BARU PADA MADRASAH ALIYAH AS-SAYAFI'IYAH 02 MENGGUNAKAN METODE TIME SERIES

Sarwo; Hermawan

PERANCANGAN SIMULASI MEDIA PEMBELAJARAN DENGAN METODE DIVISION REMAINDER UNTUK PENCARIAN ALAMAT RELATIF PADA PROSES PENEMPATAN DATA

Dewi Arianti Wulandari; Darma Rusjdi

ANALISIS SISTEM PENENTUAN LOKASI GANGGUAN JARINGAN DISTRIBUSI LISTRIK TERINTEGRASI GOOGLE MAP Abdul Haris; Herman Bedi Agtriadi

\begin{tabular}{|c|c|c|c|c|c|c|}
\hline \multirow{2}{*}{$\begin{array}{c}\text { ISSN } \\
|||||||||||||||||||||||||| \mid\end{array}$} & \multicolumn{6}{|c|}{ SEKOLAH TINGGI TEKNIK - PLN (STT-PLN) } \\
\hline & PETIR & VOL. 9 & NO. 2 & HAL. $89-166$ & JAKARTA, SEPTEMBER 2016 & ISSN 1978-9262 \\
\hline
\end{tabular}




\title{
ANALISA SPASIAL UNTUK MELIHAT TINGKAT KESEJAHTERAAN MASYARAKAT DI PROVINSI BANTEN
}

\author{
Muhamad Jafar Elly1) dan Reza Pahlevi2) \\ 1) Pranata Komputer Muda dan Pembimbing Skripsi Mahasiswa \\ 2) Mahasiswa bimbingan jurusan teknik Informatika UPN, Jakarta
}

\begin{abstract}
Abstrak
Provinsi Banten merupakan wilayah pemekaran dari provinsi induknya Jawa Barat. Posisinya yang berdekatan dengan ibukota negara berdampak terhadap kesejahteraan masyarakat di sekitarnya baik di kabupaten maupun kotamadya. Sejauh ini, data dan informasi tentang kesejahteraan di wilayah Banten belum terdistribusi secara spasial. Hal ini dirasakan kurang efektif dan informatif ketika pemerintah ingin membuat suatu kebijakan yang terkait dengan peningkatan kesejahteraan di wilayah tersebut. Penelitian ini dilakukan untuk melihat tingkat kesejahteraan masyarakat di wilayah Banten melalui pendekatan sistem informasi geografi. Data yang digunakan dalam proses analisis spasial meliputi index pembangunan manusia, kepadatan penduduk, rasio ketergantungan dan mata pencaharian. Metode yang digunakan untuk proses analisis spasial adalah pembobotan dan overlay. Hasil analisis menunjukkan bahwa rata-rata tingkat kesejahateraan di Provinsi Banten berada pada kategori sedang, yakni meliputi 116 kecamatan dari total 155 kecamatan yang tersebar di seluruh wilayah Banten. Sisanya masuk kategori cukup tinggi. Persentase tingkat kesejahteraan "Sedang" dan "Cukup Tinggi" adalah sebesar $74.83 \%$ dan $25.17 \%$. Wilayah kecamatan yang berstatus "Cukup Tinggi" terbanyak dimiliki oleh Kabupaten Tangerang, yakni sebanyak 24 kecamatan dengan persentase 15.48\%. Hasil ini diharapkan dapat dijadikan masukan bagi pemerintah daerah Provinsi Banten atau pihak-pihak yang terkait dalam rangka membuat kebijakan untuk peningkatan kualita hidup masyarakatnya.
\end{abstract}

Kata kunci : kesejahteraan, analisis spasial, Overlay

\begin{abstract}
Banten Province is an expantion area of the mother province, West Java. It is adjacent to the nation's capital have an impact on the welfare of the surrounding community either in the district or municipality. So far, the data and information about the well-being of Banten area has not been distributed spatially. This is not less effective and informative when local government wants to make a policy that related to increased welfare at the district. This study was conducted to see the level of welfare in Banten through geographic information system approach. Data used in the process of spatial analysis includes the human development index, population density, dependency ratio and livelihood. The method used to process spatial analysis is weighted and overlay. The result of analysis showed that the average level of prosperity in Banten Province was in middle category which covers 116 districts out of the 155 districts spread across Banten. The rest was categorized quite high. The percentage of welfare level "Medium"and "High Enough" amounted to $74.83 \%$ and $25.17 \%$. The sub districts have the status of "High Enough" majority owned by Tangerang district namely as many as 24 sub districts with 15.48\%. These results are expected to be used as input for the Banten Provincial Government or the related parties in order to make a policies for improving the quality of life in society.
\end{abstract}

Keywords : welfare, Spatial Analysis, Overlay

\section{PENDAHULUAN}

Kesejahteraan merupakan salah satu dari empat unsur utama pembentuk martabat manusia. Kesejahteraan berhubungan dengan berbagai macam bidang dan aspek yang harus dioptimalkan oleh pemerintah. Banten merupakan salah satu wilayah di Indonesia yang memiliki masalah kesejahteraan sosial dan belum teratasi sepenuhnya sejak lima belas tahun lalu. Wilayah Banten cukup luas dan merupakan wilayah otonom baru. Posisinya yang berdekatan dengan ibukota negara berdampak terhadap kesejahteraan masyarakat di setiap wilayah Banten baik di kabupaten maupun kotamadya. Sejauh ini, data dan informasi tentang kesejahteraan di wilayah Banten belum terdistribusi secara spasial. Hal ini tentu kurang efektif ketika pihak-pihak yang berhubungan dengan upaya peningkatan kesejahteraan di wilayah ujung barat pulau Jawa ini ingin membuat suatu kebijakan untuk perencanaan dan pembangunan ekonomi masyarakatnya. Salah satu cara yang bisa diterapkan untuk membantu pihakpihak terkait adalah dengan menggunakan sistem informasi geografi. Sistem ini mampu menjembatani dan memberikan gambaran secara spasial tentang masalah kesejahteraan masyarakat di wilayah Banten. Dengan menganalisa faktor-faktor yang berkaitan dengan dinamika kependudukan, SIG mampu menghasilkan informasi secara spasial tentang kesejahteraan masyarakat di Provinsi Banten. 
Penelitian ini difokuskan pada persoalan pemetaan kawasan tingkat kesejahteraan masyarakat di Provinsi Banten dengan menggunakan sumber data dari BPS, BIG, dan Pemerintah Provinsi Banten. Indikator pengukuran tingkat kesejahteraan yang dipakai adalah indikator kemampuan dasar, indikator kondisi penduduk, indikator beban ketergantungan dan indikator peluang pekerjaan. Tujuan penelitian adalah untuk memetakan tingkat kesejahteraan masyarakat di Provinsi Banten dan membantu pihak yang berkepentingan untuk membuat keputusan yang lebih tepat sasaran. Selain itu juga untuk melihat dinamika penduduk yang tersebar di wilayah tersebut. Luaran yang diharapkan dari penelitian ini adalah menghasilkan suatu analisa spasial tingkat kesejahteraan masyarakat di Provinsi Banten dalam bentuk pemetaan wilayah-wilayah sejahtera dengan menggunakan sistem informasi geografis.

\section{METODE PENELITIAN}

Metode penelitian meliputi pengumpulan data melalui studi pustaka dan observasi. Data kemudian diklasifikasikan berdasarkan kriteria penentu tingkat kesejahteraan masyarakat. Setelah itu, dilakukan proses analisis spasial melalui perhitungan berdasarkan pembobotan nilai-nilai tiap faktor yang diperoleh dari hasil observasi. Kemudian dilakukan proses overlay. Perancangan basis data spasial adalah langkah selanjutnya untuk mengelola data spasial.

Tahap kegiatan penelitian secara lengkap tampak dalam Gambar 1 berikut ini :

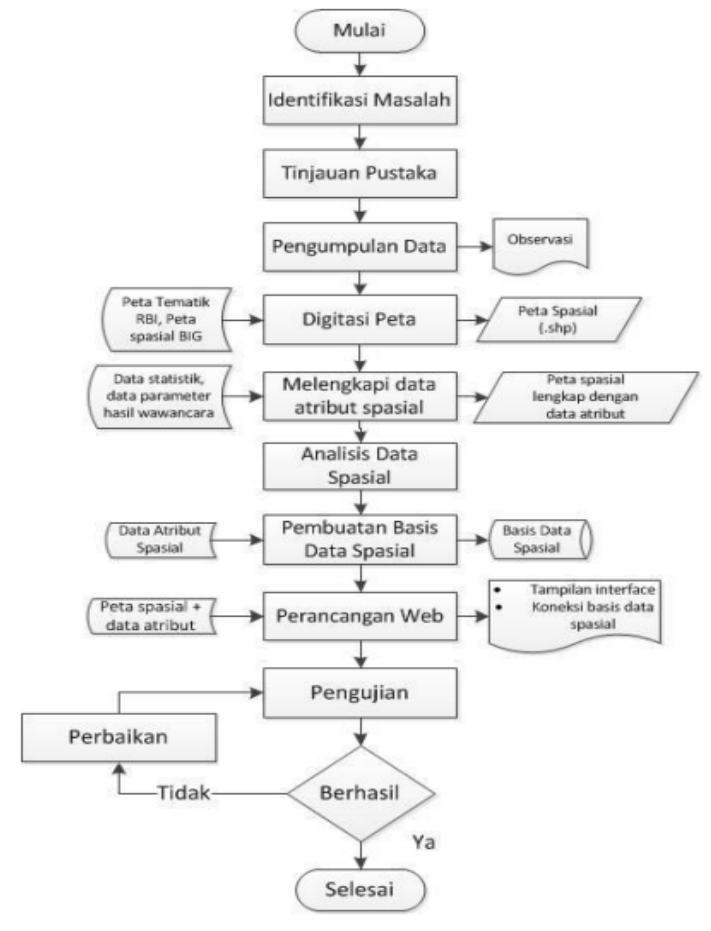

Gambar 1. Tahap-tahap penelitian yang menggambarkan kerangka pemikiran secara keseluruhan.

\section{HASIL DAN PEMBAHASAN}

\section{Proses Analisis}

Data yang telah dikumpulkan diproses melalui analisis overlay dan pembobotan. Pembobotan (weigthing) dilakukan untuk mendapatkan nilai berdasarkan bobot nilai pada tiap faktor. Data, baik dalam bentuk spasial (.shp) maupun spreadsheet (.xls) disatukan terlebih dahulu melalui proses overlay dan join table. Kemudian dilakukan pembobotan untuk menentukan nilai kriteria tingkat kesejahteraan masyarakat di wilayah Banten. Dalam penelitian ini digunakan 4 parameter pokok sebagai faktor penentu tingkat kesejahteraan masyarakat untuk memberikan gambaran tentang wilayah Provinsi Banten. Keempat faktor tersebut adalah :

\section{a. Faktor Kemampuan Dasar}

Klasifikasi faktor kemampuan dasar menggunakan nilai Indeks Pembangunan Manusia (IPM) sebagaimana tampak dalam tabel berikut ini:

Tabel 1. Klasifikasi Faktor Kemampuan Da-sar

\begin{tabular}{|l|l|l|}
\hline No & Kelas & Identifikasi \\
\hline 1 & $80-100$ & Tinggi \\
\hline 2 & $66-80$ & Menengah Keatas \\
\hline 3 & $50-66$ & Menengah Kebawah \\
\hline 4 & $<50$ & Rendah \\
\hline
\end{tabular}

\section{b. Faktor Kondisi Penduduk}

Klasifikasi faktor kondisi penduduk menggunakan nilai Kepadatan Penduduk (KP) sebagaimana tampak dalam tabel berikut ini :

Tabel 2. Klasifikasi Faktor Kondisi Penduduk

\begin{tabular}{|l|l|l|}
\hline No & Kelas & Identifikasi \\
\hline 1 & $<500 \mathrm{jiwa} / \mathrm{km}^{2}$ & Tidak Padat \\
\hline 2 & $500-4500 \mathrm{jiwa} / \mathrm{km}^{2}$ & Cukup Padat \\
\hline 3 & $4500-8500 \mathrm{jiwa} / \mathrm{km}^{2}$ & Padat \\
\hline 4 & $>8500 \mathrm{jiwa} / \mathrm{km}^{2}$ & Sangat Padat \\
\hline
\end{tabular}

\section{c. Faktor Beban Ketergantungan}

Klasifikasi faktor beban ketergantungan menggunakan nilai Rasio Ketergantungan atau Dependency Ratio (DR) sebagaima-na tampak dalam tabel berikut ini :

Tabel 3. Klasifikasi Faktor Beban Keter-gantungan

\begin{tabular}{|l|l|l|}
\hline No & Kelas & Identifikasi \\
\hline 1 & $<30$ & Rendah \\
\hline 2 & $30-40$ & Sedang \\
\hline 3 & $>40$ & Tinggi \\
\hline
\end{tabular}




\section{d. Faktor Peluang Pekerjaan}

Klasifikasi peluang pekerjaan menggunakan sub peubah penilai dari 6 sektor mata pencaharian utama, yakni Sektor Pertanian, Sektor Peternakan, Sektor Perikanan, Sektor Perdagangan, Sektor Pertambangan dan Sektor Industri. Klasifikasi faktor peluang tampak dalam tabel berikut ini :

Tabel 4. Klasifikasi Faktor Peluang Pekerjaan

\begin{tabular}{|l|l|}
\hline No & Kelas \\
\hline 1 & Besar \\
\hline 2 & Kecil \\
\hline 3 & Tidak ada \\
\hline
\end{tabular}

Berdasarkan ketentuan di atas, pembobotannya dapat dilihat pada Tabel 5 .

\section{Proses Penilaian Tingkat Kesejahteraan Masyarakat}

Kegiatan penilaian dengan sistem pembobotan pada masing-masing faktor pada umumnya dimaksudkan bahwa setiap faktor memiliki bobot pengaruh yang berbeda-beda.

Selanjutnya dalam penentuan bobot faktor bersifat relatif dan bergantung pada preferensi individu atau kelompok masyarakat dalam melihat pengaruh masing-masing faktor. Penilaian akhir identifikasi tingkat kesejahteraan masyarakat dilakukan dengan akumulasi dari hasil perhitungan terhadap faktor sebagaimana dikemukaan di atas. Berdasarkan penjumlahan berbagai peubah akan diperoleh total nilai maksimum dan minimum setiap variabel faktor.

Tabel 5. Pembobotan Tingkat Kesejahteraan Masyarakat.

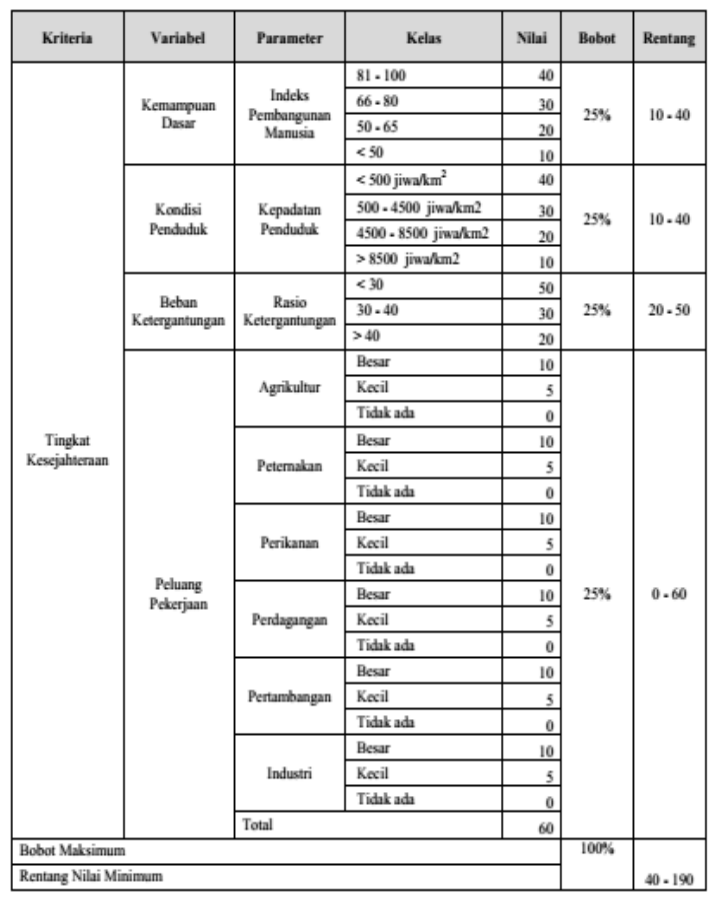

Proses penilaian menggunakan batas ambang yang dikategorikan ke dalam :
a. Kategori Tinggi
b. Kategori Cukup Tinggi
c. Kategori Sedang
d. Kategori Cukup Rendah
e. Kategori Rendah

Untuk mengklasifikasikan hasil kegiatan penilaian berdasarkan kategori tersebut, dilakukan penghitungan terhadap akumulasi bobot yang telah dilakukan dengan formula sederhana Sturgess yaitu :

a. Dihitung koefisien ambang interval (rentang) dengan cara mengurangkan Nilai Tertinggi (hasil penilaian tertinggi) dari hasil pembobotan dengan Nilai Terendah (hasil penilaian terendah) dari jumlah penilaian dibagi 5 (lima).

b. Koefisien ambang rentang sebagai pengurang dari nilai tertinggi akan menghasilkan batas nilai paling bawah dan tertinggi.

c. Untuk kategori selanjutnya dilakukan pengurangan 1 angka terhadap batas terendah dari koefisien akan menghasilkan batas tertinggi untuk kategori Cukup Tinggi, dan seterusnya.

Proses penilaian memperoleh hasil pemetaan wilayah tingkat kesejahteraan masyarakat, seperti ditunjukkan dalam diagram proses di bawah ini.

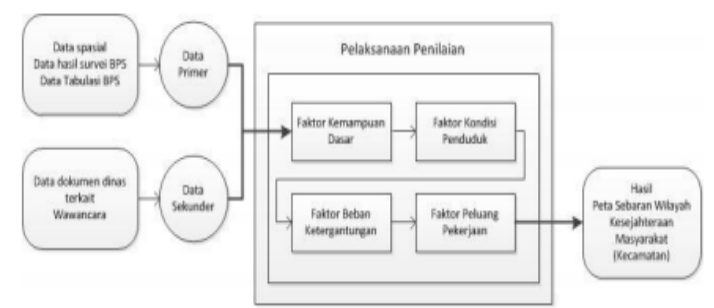

Gambar 2. Metodologi Penilaian Tingkat Kesejahteraan Masyarakat Banten

Berdasarkan koefisien ambang batas faktorfaktor kemampuan dasar manusia, kondisi penduduk, beban ketergantungan, dan peluang pekerjaan dihasilkan sebaran wilayah kesejahteraan masyarakat di provinsi Banten, dengan satuan kawasan yang telah ditetapkan sebelumnya, yaitu kecamatan. Proses ini menghasilkan klasifikasi penilaian sebagai berikut :

Tabel 6. Klasifikasi Tingkat Kesejahteraan

\begin{tabular}{|l|l|l|}
\hline No & Kelas & Identifikasi \\
\hline 1 & $40-70$ & Rendah \\
\hline 2 & $71-100$ & Cukup Rendah \\
\hline 3 & $101-130$ & Sedang \\
\hline 4 & $131-160$ & Cukup Tinggi \\
\hline 5 & $161-190$ & Tinggi \\
\hline
\end{tabular}

Hasil analisis seperti tampak dalam peta di atas menunjukkan bahwa wilayah provinsi Banten 
hanya memiliki dua jenis tingkat kesejahteraan, yaitu Sedang dan Cukup Tinggi. Kedua jenis ini tersebar ke seluruh wilayah provinsi Banten secara tidak merata. Kondisi masyarakat dengan tingkat kesejahteraan Sedang mendominasi wilayah Banten.

Hasil proses analisis spasial dapat dilihat pada Gambar 3 di bawah ini.

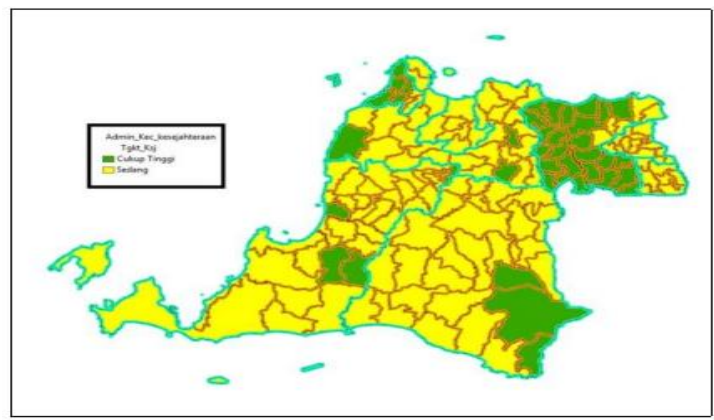

Gambar 3. Hasil Analisis Tingkat Kesejahteraan Masyarakat di Provinsi Banten

Sedangkan kondisi masyarakat dengan tingkat kesejahteraan Cukup Tinggi hanya menonjol di beberapa wilayah. Lima dari delapan wilayah di Provinsi Banten berada pada tingkat kesejahteraan Cukup Tinggi. Kelima wilayah tersebut adalah

Kabupaten Pandeglang, Kabupaten Lebak, Kabupaten Serang, Kabupaten Tangerang, dan Kota Cilegon. Sedangkan wilayah-wilayah yang termasuk tingkat kesejahteraan Sedang adalah Kota Serang, Kota Tangerang dan Kota Tangerang Selatan.

Lima dari delapan wilayah kecamatan yang tersebar di wilayah Kota Cilegon berada pada kategori tingkat kesejahteraan Cukup Tinggi, yaitu Kecamatan Ciwadan, Kecamatan Grogol, Kecamatan Purwakarta, Kecamatan Pulomerak dan Kecamatan Citangkil. Wilayah lain yang masuk kategori Cukup Tinggi adalah Kabupaten Pandeglang. Sedikitnya ada empat kecamatan yang masuk Kabupaten Pandeglang, yakni Kecamatan Pagelaran, Kecamatan Angsana, Kecamatan Koroncong, dan Kecamatan Munjul. Keempat kecamatan tersebut masing-masing tersebar (random) tidak merata pada wilayah kabupaten. Sebaran tingkat kesejahteraan Cukup Tinggi juga terdapat di Kecamatan Sobang, Kecamatan Cibeber dan Kecamatan Cilograng. Ketiga wilayah kecamatan tersebut saling berdekatan dan masuk wilayah Kabupaten Lebak. Tiga wilayah kecamatan yang berada pada kategori Cukup Tinggi tetapi tersebar tidak merata yaitu Kecamatan Kibin, Kecamatan Pamarayan, dan Kecamatan Cinangka. Ketiga wilayah kecamatan tersebut masuk wilayah Kabupaten Serang.

Wilayah dengan kategori tingkat kesejahteraan Cukup Tinggi terbanyak adalah Kabupaten Tangerang. Kabupaten ini memiliki 24 kecamatan dari 29 wilayah kecamatan yang tersebar di wilayah Banten. Kedua puluh empat wilayah tersebut adalah Kecamatan Kronjo, Kecamatan Cisauk, Kecamatan Pagedangan, Kecamatan Panongan, Kecamatan Legok, Kecamatan Cikupa, Kecamatan Sindangjaya,

Kecamatan Pakuhaji, Kecamatan Sukadiri, Kecamatan Mauk, Kecamatan Rajeg, Kecamatan Jambe, Kecamatan Tigaraksa, Kecamatan Solear, Kecamatan Cisoka, Kecamatan Balaraja, Kecamatan Kemiri, Kecamatan Mekarbaru, Kecamatan Kresek, Kecamatan

Gunungkaler, Kecamatan Jayanti, Kecamatan Sukamulya, Kecamatan Kelapa Dua, dan Kecamatan Curug. Secara visual Kabupaten Tangerang memperlihatkan pengelompokkan (cluster) terbesar dan kondisinya lebih baik dibandingkan dengan ketujuh wilayah lainnya. Ini menandakan bahwa Kabupaten Tangerang memiliki kategori tingkat Kesejahteraan Cukup Tinggi terbanyak untuk tahun 2013.

Tabel 13. Jumlah Kecamatan Yang memiliki Tingkat Kesejahteraan Pada Lingkup Wilayah Kabupaten dan Kota

\begin{tabular}{|c|c|c|c|c|c|}
\hline No & Nama & $\begin{array}{c}\text { Total } \\
\text { Kecamatan }\end{array}$ & Status & Jumlah & $\begin{array}{c}\text { Persentase } \\
\text { (\%) }\end{array}$ \\
\hline \multirow{2}{*}{1} & \multirow{2}{*}{ Kab. Pandeglang } & \multirow{2}{*}{35} & Sedang & 31 & 20 \\
\hline & & & Cukup Tinggi & 4 & 2.58 \\
\hline \multirow{2}{*}{2} & \multirow{2}{*}{ Kab. Lehak } & \multirow{2}{*}{28} & Sedang & 25 & 16.12 \\
\hline & & & Cukup Tinggi & 3 & 1.94 \\
\hline \multirow{2}{*}{3} & \multirow{2}{*}{ Kab. Tangerang } & \multirow{2}{*}{29} & Sedang & 5 & 3.23 \\
\hline & & & Cukup Tinggi & 24 & 15.48 \\
\hline \multirow{2}{*}{4} & \multirow{2}{*}{ Kab. Serang } & \multirow{2}{*}{29} & Sedang & 26 & 16.77 \\
\hline & & & Cukup Tinggi & 3 & 1.94 \\
\hline \multirow{2}{*}{5} & \multirow{2}{*}{ Kota Cilegon } & \multirow{2}{*}{8} & Sedang & 3 & 1.94 \\
\hline & & & Cukup Tinggi & 5 & 3.23 \\
\hline \multirow{2}{*}{6} & \multirow{2}{*}{ Kota Serang } & \multirow{2}{*}{6} & Sedang & 6 & 3.87 \\
\hline & & & Cukup Tinggi & 0 & 0 \\
\hline \multirow{2}{*}{7} & \multirow{2}{*}{ Kota Tangerang } & \multirow{2}{*}{13} & \begin{tabular}{|l|} 
Sedang \\
\end{tabular} & 13 & 8.38 \\
\hline & & & Cukup Tinggi & 0 & 0 \\
\hline \multirow{2}{*}{8} & \multirow{2}{*}{$\begin{array}{l}\text { Kota Tangerang } \\
\text { Selatan }\end{array}$} & \multirow{2}{*}{7} & Sedang & 7 & 4.52 \\
\hline & & & Cukup Tinggi & 0 & 0 \\
\hline \multirow{2}{*}{9} & \multirow{2}{*}{ Provinsi Banten } & \multirow{2}{*}{155} & Sedang & 116 & 74.83 \\
\hline & & & Cukup Tinggi & 39 & 25.17 \\
\hline
\end{tabular}

Berikut ini hasil analisis tingkat kesejahteraan masyarakat di Provinsi Banten dalam bentuk peta tematik pada tingkat administrasi kecamatan yang terbagi dalam wilayah kabupaten dan kota.

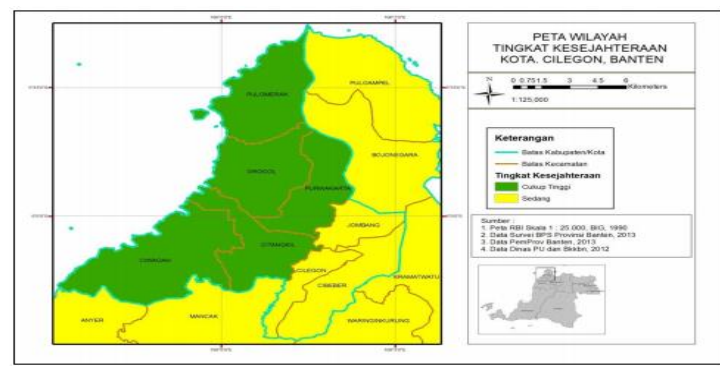

Gambar 4. Peta Tingkat Kesejahteraan di Kabupaten Pandeglang 


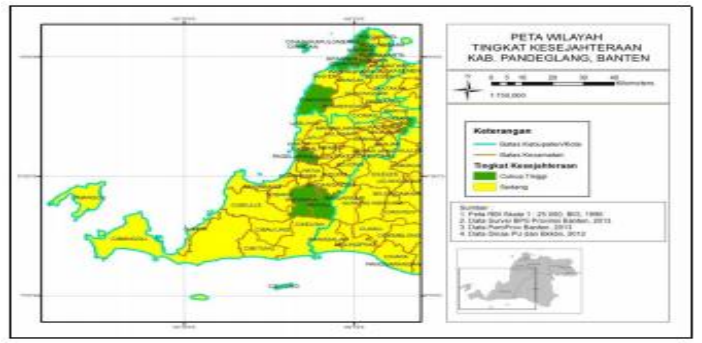

Gambar 5. Peta Tingkat Kesejahteraan di Kabupaten Serang

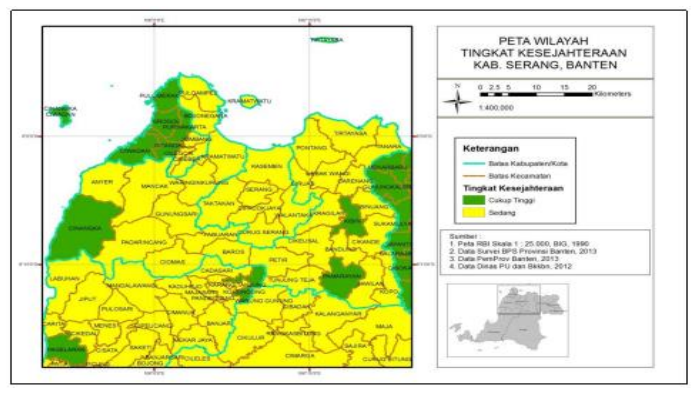

Gambar 6. Peta Tingkat Kesejahteraan di Kota Cilegon

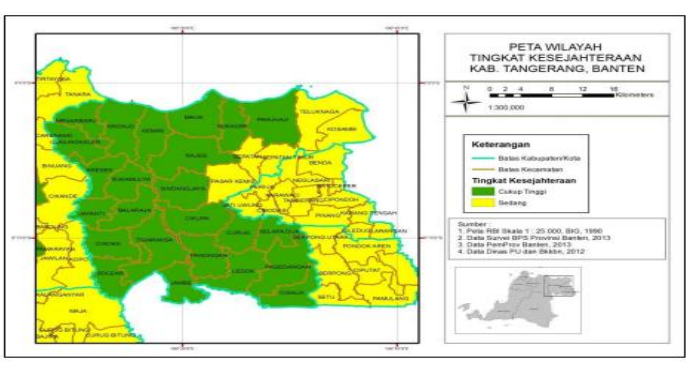

Gambar 7. Peta Tingkat Kesejahteraan di Ka-bupaten Tangerang

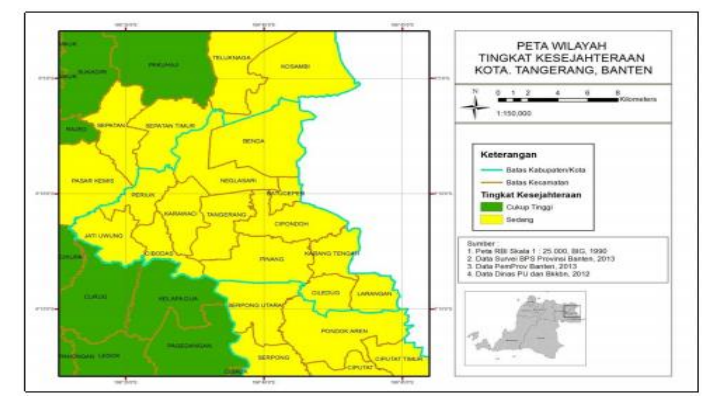

Gambar 8. Peta Tingkat Kesejahteraan di Kota Tangerang

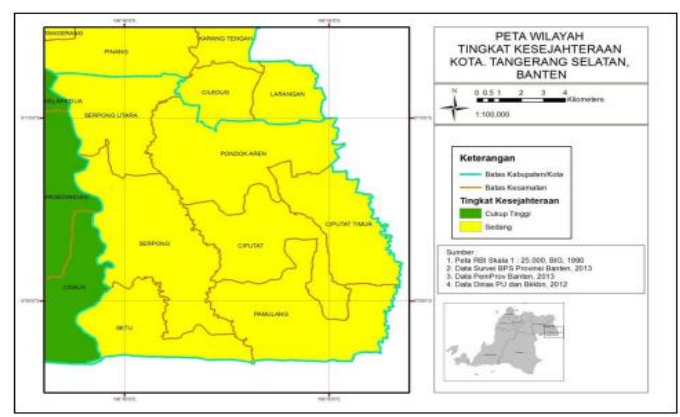

Gambar 9. Peta Tingkat Kesejahteraan di Kota Tangerang Selatan

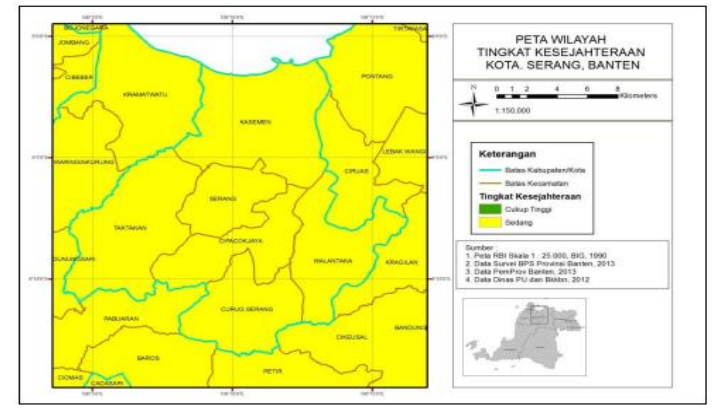

Gambar 10. Peta Tingkat Kesejahteraan di Kota Serang

\section{SIMPULAN}

Berdasarkan hasil dan pembahasan di atas dapat disimpulkan bahwa:

a. Tingkat kesejahteraan masyarakat di Provinsi Banten sebagian besar berstatus sedang. Hal ini tampak dari total 155 kecamatan di Provinsi Banten, 39 kecamatan di antaranya menunjukkan status tingkat kesejahteraan Cukup Tinggi dan 116 kecamatan menunjukkan status tingkat kesejahteraan Sedang. Persentase jumlah antara wilayah dengan tingkat kesejahteraan "Sedang" dan "Cukup Tinggi" adalah sebesar $74.83 \%$ dan $25.17 \%$. Wilayah kecamatan yang berstatus "Cukup Tinggi" terbanyak dimiliki oleh Kabupaten Tangerang sebanyak 24 kecamatan dengan persentase $15.48 \%$.

b. Sebagian besar wilayah kecamatan berstatus Cukup Tinggi membentuk kelompok (cluster) berada pada sisi utara Provinsi Banten tepatnya mengumpul pada wilayah Kabupaten Tangerang sebanyak 24 kecamatan dan sisanya tersebar (random) secara acak dan membentuk kelompokkelompok kecil di 3 wilayah kabupaten dan 1 wilayah kota.

\section{DAFTAR PUSTAKA}

Ananta, A 1993, Ciri Demografis Kualitas Penduduk Dan Pembangunan Ekonomi, Jakarta : Lembaga demografi dan lembaga penerbit Fakultas Ekonomi Fakultas Indonesia.

Anselin, Getis Ord, 1992, Exploratory Spatial Data Analysis (ESDA).

Bintarto 1989, Interaksi Desa-Kota dan Permasalahannya, Ghalia Indonesia, Jakarta.

BPS, Survei Biaya Hidup (SBH) tahun 1989, Jakarta.

BPS Provinsi Banten 2014, Provinsi Banten Dalam Angka 2014, Jakarta.

Denny Carter, Irma Agtrisari 2003, Desain dan Aplikasi SIG, Elex Media Komputindo, Jakarta.

Departemen Pekerjaan Umum, 2006, Identifikasi Kawasan Permukiman Kumuh Penyangga Kota Metropolitan, Jakarta. 
Undang-Undang Republik Indonesia No 4 Tahun 2011 tentang tata kelola informasi geospasial, Jakarta.

Jafar, M.E 2008, SISTEM INFORMASI GEOGRAFIS Menggunakan Aplikasi

ArcView 3.2 dan ERMapper 6.4, Edisi Pertama, Graha IImu, ISBN: 978-979-756-497-1, Yogyakarta.

Nasikun 1993, Urbanisasi dan Kemiskinan di Dunia Ketiga, PT. Tiara Wacana, Yogyakarta.

Pemerintah Provinsi Banten 2011, Rencana Pembangunan Jangka Menengah Daerah (RPJMD) 2012-2017. Tersedia dari : Publikasi Pemerintah Provinsi Banten.
Prahasta, E 2002, Konsep-konsep dasar SIG, Informatika, Bandung.

Todaro, M.P 2003, Pembangunan Ekonomi Di Dunia Ketiga, Edisi Keenam, hal. 76, Gramedia, Jakarta.

Rommey, 1997, Fungsi sistem informasi, diakses 26 september 2015.

\section{Sumber internet :}

http://www.dosenpendidikan.com/12-penger-tiandan-fungsi-sistem-informasi-menurut-paraahli/ 